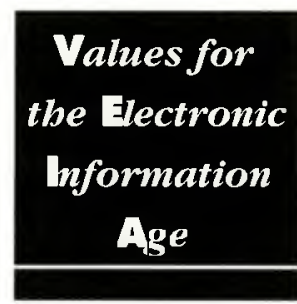

\title{
Facing the new millennium
}

By W. Lee Hisle

\section{Traditional values are still relevant in the electronic information age}

E d. Note: This is the first in a series of columns that will explore ACRL president Lee Hisle's theme of "Facing the Millennium: Values for the Electronic Age." Next month, Katherine Brancb will contribute a column

As I considered what my theme might be for my year as President of ACRL, I knew it should have two characteristics: one, that it would deal with the impact of electronic information on our profession, and two, that it would deal more with inquiry than fact. I wanted a theme that would encourage members to think about issues central to our profession. Thus, I chose the theme, "Facing the Millennium: Values for the Electronic Information Age." I believe that some of the traditional values of $\mathrm{li}$ brarianship are being challenged and, perlaps, are changing as a result of the advancing electronic age. In librarianship, I see a profession seeking reaffirmation of traditional values even as it questions them. Because of this, I wanted a theme that allowed ACRL members an opportunity to explore their own personal values in relation to those of our profession.

\section{Challenges to our values}

Challenges to our values surround us, as indicated by the debates over the appropriate use of filtering software and the seemingly cavalier abrogation of "fair-use" tenets in the licensing agreements we sign. In times of change, people and institutions seek stability. I believe that stability can come from our values; not from the way we do things, but by the beliefs we hold as immutalsle. By reaffirming, by changing when necessary, but most of all, by understanding those values most critical to us and to our profession, we can move into the future with confidence.

Which of our values are being challenged? One of the more important is an altruistic sense of service. In fact, many of us come to the profession with a missionary zeal for service: we believe we can make a difference in people's lives and in the quality of our society. Recently I was engaged in a discussion about eliminating the print option from our electronic catalog and databases. Printing is a costly service for the college to provide, and cost-recovery systems for printing from electronic resources are in their infancy. It was proposed that all students using electronic sources in our college download their information and print it off-campus. Yet, consiclering some 60 percent of our students do not have PCs at home, our value of service argues for a free or low-cost printing solution on campus. It is the service value that

\section{I believe that stability can} come from our values: not from the way we do things, but by the beliefs we hold as immutable. drives that argument. Without that value, the decision might have been made to avoid the inconvenience, and cost, of printing facilities and eliminate a current and valuable service.

\section{Intellectual freedom}

The conflict surrounding intellectual freedom in an electronic environment offers another

W. Lee Hisle is the president of ACKL and the associate vice president for Learning Resontre Services at Austin Community College; e-mail: hisle@austin.cc.tx.us 


\section{Join ACRL President's Midwinter discussion forum: Enduring values for the new millennium}

Are you concerned that the commercialization of electronic information may erode equitable access to information for acaclemic library patrons? Do you spend sleepless nights wondering whether the commitment of academic librarians to intellectual freedom will be compromised by protests against explicit materials on the Internet? Do you worry about how academic librarians will uphold our service values, our professional neutrality, and the tenets of fair use in today's political and economic climate?

If so, make plans to attend the ACRL President's Discussion Forum "Enduring Val- ues for the New Millennium" at the ALA Midwinter Meeting in New Orleans. This discussion forum, to be moderated by Shelley Phipps of the University of Arizona, will explore ACRL President Lee Hisle's theme of values for the electronic information age. Scenarios will be presented, and attendees will have the opportunity to engage in group discussions about values important to academic librarians. "Encluring Values for the New Millennium" will take place Monclay, January 12, 9:30-11:00 a.m. Check the official conference program for exact meeting room location.

\section{Biotechnology cont. from 762}

This Web page provides links to documents related to issues and ethics, the Human Genome Project, Principles of Genetic Engineering, and the State of the Art. Access: hutp: www.gene.com/ae/AB/IF/

- Public Perception Issues in Biotechnology. The goal of this Web site is "to provide information on communication of biotechnology issues and the impact of biotechnology on society." Issues covered are scientific, regulatory, educational, and commercial, with a focus on issues related to agriculture and the environment. Access: http://www.vt.edu: 10021 / cals/cses/chagedor/percep.html.

- Biotechnology: Public PerceptionsPublic Information (BIC). A collection of Web sites and documents that deal with bioethics and public attitudes and perceptions towards biotechnology. Access: http://www.nal.usda.gov/bic/ www. html \#percep.

- Center for Biotechnology Policy and Ethics. This center at Texas A\&M University "was created in 1990 as a specific response to ethical and political challenges facing the development of new generic technologies, especially in the food, agricultural and natural resource sectors." Through discussion groups. conferences, and workshops, this forum for interdisciplinary research brings together individuals and organizations involved in biotechnology and its impact on society. Access: http:/ wuw.tamu.edu/chpe/ 